\title{
USEFULNESS OF EARLY DIAGNOSTIC METHODS FOR EFFECTIVE MANAGEMENT OF BASAL STEM ROT (GANODERMA) DISEASE OF COCONUT
}

By

\author{
A. Karthikeyan, S. Mohan and R. Bhaskaran ${ }^{1}$
}

\begin{abstract}
Chemodiagnostic methos EDTA and TTC tests and physiological parameters electrical conductivity and relative water content are useful to detect the basal stem rot disease in coconut palms, 4 - 14 months before visual symptom expression. The critical values of these tests for symptom expression have been fixed. In coconut trees, root sampling from any directions at $15-30 \mathrm{~cm}$ depth is optimum for early detection tests. Coconut palms without symptoms but showing higher values in diagnostic tests responded well to treatments by registering lesser disease index and higher nut yield than the treated palms with external symptoms.
\end{abstract}

\section{INTRODUCTION}

Basal stem rot or Ganoderma wilt caused by Ganoderma lucidum (Leys). Karst is a lethal disease affecting coconut production in India. The Characteristic symptoms of the disease are oozing out

1 Coconut Research Station, Tamil Nadu Agricultural University, Veppankulam 614 906, Tamil Nadu, India. 
of brown liquid from the basal portions of the stem, drooping and drying of leaves starting from lower whorl to top spindle leaf, heavy button shedding, upward extension of stem decay and death of palm. The diseased palms normally die within a period of $6-24$ months from the appearance of initial visual symptoms (Bhaskaran, et al., 1989) Integrated disease management practices like root feeding of fungicides $1.3 \mathrm{~g}$ aureofungin-sol $+0.5 \mathrm{~g}$ copper sulphate or $2 \mathrm{ml}$ tridemorph in $100 \mathrm{ml}$ water and soil drenching of 40 litres of $1 \%$ Bordeaux mixture, soil application of $5 \mathrm{~kg}$ neem cake, $500 \mathrm{~g}$ inoculum of Trichoderma harzianum multiplied in $50 \mathrm{~kg}$ farm manure and banana intercropping are recommended to contain the disease (Bhaskaran et al., 1994). Appearance of bleeding patches or exudation of brown liquid from the basal portion of the stem is the initial visual symptom of the disease. By the time of dependable or clear cut visual symptoms appear in the palms, much damage has already been done to the palms. All the recommended disease control measures will be effective, only if the palms are treated in early stages of infection. Hence, developing some methods/ techniques for early identification of basal stem rot (BSR) affected palms will be useful in the management of the disease.

Earlier works have attempted to develop some methods for the early diagnosis of the disease before visual symptom expression. Preliminary investigations indicated that few chemodiagnostic tests and physiological parameters were found to be useful tools for early detection of coconut diseases. Natarajan et al., (1986) reported that biochemical tests like 'Iodine - potassium iodide'staining technique, $\mathrm{KOH}$ method and EDTA method were useful for early detection of the disease. Physiological parameters like leaf water content, transpiration rate and stomatal resistance were reported to be helpful for the early detection of root (wilt) disease of coconut caused by Mycoplasma like organisms (Rajagopal et al., 1986, 1987). In the present study, some promising chemodiagnostic and physiological 
tests have been developed, the methodologies of the diagnostic tests are standardized, procedure for root sampling in the field and the usefulness of early diagnostic tests for the management of the disease have been reported.

\section{MATERIALS AND METHODS}

Field experiments and laboratory tests have been conducted at Coconut Research Station, Veppankulam during 1995 - 2000 to find out the promising early diagnostic tests, standardizing their methodologies and to study their utility in disease management under field condition. Various laboratory diagnostic tests viz., estimation of bio chemical constituents, enzyme activities, biochemical tests/staining techniques using dyes and salts and physiological parameters were performed for the early detection of the disease.

Chemodiagnostic tests Ethylene diamine tetra acetic acid disodium salt (EDTA) method Triphenyl Tetrazolium Chloride (TTC) method and physiological parameters relative water content (RWC) and electrical conductivity (EC) were found to be reliable tests.

\section{Chemodiagnostic tests}

\section{i) EDTA (Ethylene diamine tetra acetic acid - di sodium salt) Test}

One gram of chopped root tissue was immersed in $10 \mathrm{ml}$ of $0.3 \mathrm{M}$ ethylene diamine tetra acetic acid - disodium salt solution. The optical density (O.D) values are then recorded in supertonic - 20 colorimeter at $400 \mathrm{~nm}$ after one hour of incubation. 


\section{ii) Triphenyl Tetrazolium Chloride (TTC) test:}

One gram of root tissues chopped into small pieces were immersed in $10 \mathrm{ml}$ of $0.1 \% \quad 2,3,5$ triphenyl tetrazolium chloride solution for a period of $24 \mathrm{hrs}$. After incubation, the optical density values were recorded in supertonic - 20 colorimeter at $460 \mathrm{~nm}$ (Karthikeyan, 1995).

\section{Physiological parameters}

\section{i) Electrical conductivity (EC):}

Coconut root tissues $(1 \mathrm{gm})$ were placed in $100 \mathrm{ml}$ beaker containing $40 \mathrm{ml}$ of distilled water. One hour after incubation, the electrical conductivity of the ambient solution was measured in a digital conductivity bridge .

\section{ii) Relative water content (RWC)}

The leaf relative water content was calculated as below

$$
\mathrm{RWC}=\frac{\text { Fresh weight }- \text { Dry weight }}{\text { Turgid weight }- \text { Dry weight }} \text { x } 100
$$

Turgid weight was estimated by taking the leaf samples in petridishes containing water for four hours (Bennett et al., 1981).

\section{Root sampling for early diagnostic tests:}

Since the coconut tree has extensive root system with plenty of adventitious roots, the root sampling procedure is very important for correct diagnosis with chemical or physiological tests. Appropriate root sampling alone will give accurate and reliable 
results in diagnostic tests. So root sampling depth and direction for early diagnostic tests have been standardized.

To find out the optimum depth of root sampling for early diagnostic tests, roots from healthy and diseased palms were collected in the basin area of $1.8 \mathrm{~m}$ radius at different depths viz., 5, $15,30,45 \mathrm{~cm}$ and subjected to the EDTA and TTC tests. Root samples were collected from East, West, North and South directions of coconut palms at $15-30 \mathrm{~cm}$ depth to undertake early diagnostic tests.

\section{IV) Field testing of early diagnostic tests}

Two hundred and twenty five apparently healthy palms adjacent to fifty diseased palms were selected from four gardens in the disease endemic areas for field testing of diagnostic tests. Periodical analysis of coconut palms with early detection techniques were attempted to fix up critical values.

\section{V) Usefulness of diagnostic tests for disease management}

A field experiment was laid out during August 1998 in disease endemic area to find out the utility of the early detection test for the management of the disease. Observations on disease intensity and nut yield were recorded in the trees with and without basal stem rot symptoms(but with high O.D values in EDTA and TTC tests) and in treated and untreated trees.

\section{RESULTS AND DISCUSSION}

In the chemodiagnostic tests EDTA and TTC tests, BSR affected root tissues recorded higher optical density (O .D ) values than the healthy root tissues. The O.D. values increased with 
increase in disease intensity (Table 1). The results of the EDTA test are found to be in accordance with the findings of Kamala Thirumalaiswamy et al., (1992) . The physiological parameter, electrolyte leakage or conductivity (E.C) was higher in root tissues of diseased palms as compared to healthy palms. The E.C increased with increase in disease severity. In BSR affected coconut palms, the leaf relative water content (RWC) was lesser than the healthy palms. The leaf water content was negatively correlated with disease intensity. The demarcation of healthy and diseased coconut tissues in chemodiagnostic and physiological tests is useful for the early diagnosis of the disease.

Significant difference in O.D values were observed between healthy and diseased tissues collected at various depths in EDTA and TTC tests. However the effect was more pronounced in the roots collected at $15-30 \mathrm{~cm}$ depth (Table 2). The results (Table 3) indicated that there was no marked difference in the O.D. values of healthy and diseased root samples obtained from four different directions. It is concluded that root sampling at $15-30 \mathrm{~cm}$ depth from any directions of the palm is found optimum for early detection tests.

Promising chemodiagnostic and physiological methods were employed in large scale testing under field condition at periodical intervals to fix up the critical levels for early diagnosis of the disease. Sixty four apparently healthy coconut palms out of 225 coconut palms tested, expressed disease symptoms during the experimental period. They showed the critical values/ levels as 0.20 in EDTA test and 0.14 in TTC test. The critical values of physiological characters E.C and RWC were as $88.0 \mu \mathrm{s} \mathrm{s}^{-1}$ and 50.2 percent respectively (Table 4). The apparently healthy coconut palms showed the critical values in the early diagnostic tests, 4 - 14 months before visual symptom expression. 
All the above diagnostic tests are dependable, only when they are helpful to contain the disease in the field. In the field experiment on the utility of early diagnostic tests for disease management (Table 5 ), the coconut trees without visual symptoms (but showed higher values than critical level in early detection tests) applied with recommended disease management practices registered a lower disease index (3.26) as compared to the coconut trees showing visual symptoms with treatment (15.80) and without treatment (39.52). The nut yield was increased in treated coconut palms without symptoms but identified as infected palms by diagnostic techniques.

Hence, it is concluded that any of these diagnostic techniques can be used for early identification of BSR infected coconut trees in the field and for the most effective disease management in coconut.

\section{REFERENCES}

Bennett, J.M., Boote, K.J. and Hammand, L.C. 1981. Alterations in the components of peanut leaf water potential during desiccation. J. Expl. Bot., 32 : 1035 - 1043

Bhaskaran, R., Rethinam, P. and Nambiar, K.K.N. 1989. Thanjavur wilt of coconut. J. Plantation Crops, $17: 69-79$

Bhaskaran, R., Rethinam, P. and Nambiar, K.K.N 1994. Ganoderma wilt disease of coconut. In: Advances in Horticulture No.10 - 
Plantation Crops and Spice Crops, Part.2 (Ed.) K.L.Chadha and P. Rethinam.

Kamala Thirumalaiswamy, Vijayaraghavan, H., and Joseph Savery. 1992. Early diagnosis of Thanjavur wilt of coconut. Indian Coconut Journal, 23 (5) : 9 - 10

Karthikeyan, A. 1995. Chemodiagnostic methods for early detection of Thanjavur wilt of coconut. Plant Disease Research 10 (2) : $168-170$.

Natarajan, S., Bhaskaran, R., and Shanmugam, N. 1986. Preliminary studies to develop techniques for early detection of Thanjavur wilt in coconut. Indian Coconut Journal, 17 (3): 3 - 6.

Rajagopal, V., Patil, K.D. and Sumathy kutty Amma,B . 1986. Abnormal opening in coconut palms affected with root (wilt) disease. J. Expl. Bot., 37 : 1398 - 1405

Rajagopal, V., Sumathy kutty Amma, B. and Patil, K.D. 1987. Water relations of coconut palms affected with root (wilt) disease. New Phytol., 105 : 289 - 293 
Table. 1: O.D. values in chemodiagnostic tests and physiological parameters of healthy and BSR affected coconut palms.

\begin{tabular}{|c|c|c|c|c|c|}
\hline \multirow{2}{*}{ Plant Sample } & \multirow{2}{*}{$\begin{array}{l}\text { Disease } \\
\text { index }\end{array}$} & \multicolumn{2}{|c|}{ Optical density values* } & \multirow{2}{*}{$\begin{array}{c}\text { Electrical } \\
\text { conductivity } \\
\left(\mu \mathrm{s} \mathbf{s}^{-1}\right)\end{array}$} & \multirow{2}{*}{$\begin{array}{c}\text { Relative } \\
\text { water } \\
\text { content } \\
(\%) \\
\end{array}$} \\
\hline & & EDTA test & TTC test & & \\
\hline Diseased - mild & Below 15 & 0.28 & 0.18 & 52.4 & 92.4 \\
\hline Diseased - moderate & $15-40$ & 0.36 & 0.24 & 50.1 & 93.8 \\
\hline Diseased - severe & Above 40 & 0.62 & 0.38 & 49.0 & 112.0 \\
\hline Apparently healthy & - & 0.12 & 0.08 & 56.5 & 74.4 \\
\hline Healthy & - & 0.09 & 0.06 & 59.7 & 73.2 \\
\hline C.D $(\mathrm{P}=0.05)$ & - & 0.04 & 0.03 & 1.46 & 4.80 \\
\hline
\end{tabular}

?? Mean of 10 replications

Table 2: O.D. values of BSR affected and healthy root samples collected at different depths in chemodiagnostic tests.

\begin{tabular}{|l|l|c|c|c|c|c|}
\hline \multirow{2}{*}{$\begin{array}{c}\text { Sampling } \\
\text { depth } \\
(\mathbf{c m})\end{array}$} & \multicolumn{2}{|c|}{ EDTA test (O.D. at 400 nm)* } & \multicolumn{3}{c|}{ TTC test (O.D at 460 nm)* } \\
\cline { 2 - 7 } & Healthy & Diseased & $\begin{array}{c}\text { Difference } \\
\text { in OD }\end{array}$ & Healthy & Diseased & $\begin{array}{c}\text { Difference } \\
\text { in O.D }\end{array}$ \\
\hline 5 & 0.18 & 0.53 & 0.35 & 0.03 & 0.19 & 0.16 \\
\hline 15 & 0.09 & 0.56 & 0.47 & 0.05 & 0.29 & 0.24 \\
\hline 30 & 0.07 & 0.57 & 0.50 & 0.04 & 0.30 & 0.26 \\
\hline 45 & 0.17 & 0.50 & 0.33 & 0.08 & 0.22 & 0.14 \\
\hline Mean & 0.13 & 0.54 & 0.41 & 0.05 & 0.25 & 0.20 \\
\hline
\end{tabular}

?? Mean of 10 replications

$\begin{array}{lcll}\text { EDTA test } & \text { C.D }(\mathbf{P}=\mathbf{0 . 0 5}) & \text { TTC test } & \text { C.D }(\mathbf{P}=\mathbf{0 . 0 5}) \\ \text { Disease } & 0.04 & \text { Disease } & 0.03 \\ \text { Depth } & 0.09 & \text { Depth } & 0.06 \\ \text { Interaction } & 0.18 & \text { Interaction } & 0.11\end{array}$


Table 3 : O.D. values of BSR affected and healthy root samples collected at different directions in chemodiagnostic tests.

\begin{tabular}{|c|c|c|c|c|c|c|}
\hline \multirow{2}{*}{$\begin{array}{c}\text { Samplin } \\
\begin{array}{c}\text { g } \\
\text { depth } \\
(\mathbf{c m})\end{array}\end{array}$} & \multicolumn{2}{|c|}{ EDTA test (O.D at 400 nm)* } & \multicolumn{3}{|c|}{ TTC test (O.D at 460 nm)* } \\
\cline { 2 - 7 } & Healthy & Diseased & $\begin{array}{c}\text { Diffe- } \\
\text { rence } \\
\text { in OD }\end{array}$ & Healthy & Diseased & $\begin{array}{c}\text { Diffe- } \\
\text { rence in } \\
\text { O.D. }\end{array}$ \\
\hline East & 0.24 & 0.44 & 0.20 & 0.04 & 0.24 & 0.20 \\
\hline West & 0.28 & 0.46 & 0.18 & 0.06 & 0.26 & 0.20 \\
\hline North & 0.24 & 0.50 & 0.26 & 0.05 & 0.26 & 0.21 \\
\hline South & 0.23 & 0.46 & 0.23 & 0.05 & 0.27 & 0.22 \\
\hline Mean & 0.25 & 0.47 & 0.22 & 0.05 & 0.26 & 0.21 \\
\hline
\end{tabular}

* Mean of 10 replications

$\begin{array}{llll}\text { EDTA test } & \text { C.D }(\mathbf{P = 0 . 0 5}) & \text { TTC test } & \text { C.D }(P=0.05) \\ \text { Disease } & 0.05 & \text { Disease } & 0.04 \\ \text { Directions } & \text { N.S } & \text { Directions } & \text { N.S } \\ \text { Interaction } & 0.08 & \text { Interaction } & \text { N.S }\end{array}$

Table 4 : Critical levels of apparently healthy palms in chemodiagnostic and physiological tests.

\begin{tabular}{|l|c|c|c|}
\hline \multirow{2}{*}{ Diagnostic tests } & \multicolumn{2}{|c|}{ Test values (range) } & \multirow{2}{*}{ Critical Level* } \\
\cline { 2 - 3 } & Initial & $\begin{array}{c}\text { After 14 } \\
\text { months }\end{array}$ & 0.20 \\
\hline $\begin{array}{l}\text { EDTA test } \\
(\text { O.D at } 400 \mathrm{~nm})\end{array}$ & $0.04-0.60$ & $0.14-0.75$ & 0.14 \\
\hline $\begin{array}{l}\text { TTC test } \\
(\mathrm{O} . \mathrm{D} \text { at } 460 \mathrm{~nm})\end{array}$ & $0.02-0.40$ & $0.08-0.70$ & 88.0 \\
\hline $\begin{array}{l}\text { E.C test } \\
\left(\boldsymbol{\mu s} \mathbf{s}^{-1}\right)\end{array}$ & $40.0-95.6$ & $54.9-108.0$ & 50.2 \\
\hline $\begin{array}{l}\text { Relative Water } \\
\text { Content }(\%)\end{array}$ & $56.0-63.5$ & $45.0-59.0$ & \\
\hline
\end{tabular}


* Critical level at which symptom expression takes place in coconut palms.

Table 5: Usefulness of early diagnostic tests for the management of basal stem rot disease of coconut

\begin{tabular}{|c|c|c|c|c|c|}
\hline \multirow[b]{2}{*}{ Treatments } & \multicolumn{3}{|c|}{ Disease index* } & \multicolumn{2}{|c|}{$\begin{array}{c}\text { Mean nut } \\
\text { yield/palm/year* }\end{array}$} \\
\hline & $\begin{array}{c}\text { Initial } \\
\text { (Aug'98) }\end{array}$ & $\begin{array}{c}\text { Upto } \\
\text { Oct' } 2000\end{array}$ & $\begin{array}{c}\text { Increase } \\
\text { over initial }\end{array}$ & $\begin{array}{l}\text { Pre- } \\
\text { treat- } \\
\text { ment }\end{array}$ & $\begin{array}{l}\text { Treatment } \\
\text { period } \\
\text { 1998- 2000 }\end{array}$ \\
\hline $\begin{array}{l}\text { Trees without } \\
\text { symptoms } * * \\
\text { - treated }\end{array}$ & - & 3.26 & 3.26 & 80 & 90 \\
\hline - Untreated & - & 18.40 & 18.40 & 102 & 83 \\
\hline $\begin{array}{l}\text { Trees with } \\
\text { symptoms } * * \\
\text { - treated }\end{array}$ & 12.16 & 15.80 & 3.64 & 104 & 94 \\
\hline -Untreated & 14.12 & 39.52 & 25.40 & 94 & 67 \\
\hline C.D (P - 0.05) & NS & 7.74 & - & NS & 6 \\
\hline
\end{tabular}

* Mean of six replications

** Trees without symptoms showing high O.D values in early diagnostic tests. 